\title{
Solamargine, a bioactive steroidal alkaloid isolated from Solanum aculeastrum induces non-selective cytotoxicity and P- glycoprotein inhibition
}

Trevor Burger ${ }^{1}$, Tsholofelo Mokoka ${ }^{2}$, Gerda Fouché ${ }^{2}$, Paul Steenkamp ${ }^{2,3}$, Vanessa Steenkamp ${ }^{1}$ and Werner Cordier ${ }^{1 *}$ (D)

\begin{abstract}
Background: Solanum aculeastrum fruits are used by some cancer sufferers as a form of alternative treatment. Scientific literature is scarce concerning its anticancer activity, and thus the aim of the study was to assess the in vitro anticancer and P-glycoprotein inhibitory potential of extracts of S. aculeastrum fruits. Furthermore, assessment of the combinational effect with doxorubicin was also done.

Methods: The crude extract was prepared by ultrasonic maceration. Liquid-liquid extraction yielded one aqueous and two organic fractions. Bioactive constituents were isolated from the aqueous fraction by means of column chromatography, solid phase extraction and preparative thin-layer chromatography. Confirmation of bioactive constituent identity was done by nuclear magnetic resonance and ultra-performance liquid chromatography mass spectrometry. The crude extract and fractions were assessed for cytotoxicity and P-glycoprotein inhibition in both cancerous and non-cancerous cell lines using the sulforhodamine B and rhodamine-123 assays, respectively.

Results: Both the crude extract and aqueous fraction was cytotoxic to all cell lines, with the SH-SY5Y neuroblastoma cell line being most susceptible to exposure ( $\left(C_{50}=10.72 \mu \mathrm{g} / \mathrm{mL}\right.$ [crude], $17.21 \mu \mathrm{g} / \mathrm{mL}$ [aqueous]). Dose-dependent P-glycoprotein inhibition was observed for the crude extract (5.9 to 18.9-fold at $100 \mu \mathrm{g} / \mathrm{mL}$ ) and aqueous fraction (2.9 to 21.2 at $100 \mu \mathrm{g} / \mathrm{mL}$ ). The steroidal alkaloids solamargine and solanine were identified. While solanine was not bioactive, solamargine displayed an $\mathrm{IC}_{50}$ of $15.62 \mathrm{\mu g} / \mathrm{mL}$, and 9.1 -fold P-glycoprotein inhibition at $100 \mathrm{\mu g} / \mathrm{mL}$ against the SH-SY5Y cell line. Additive effects were noted for combinations of doxorubicin against the SH-SY5Y cell line.

Conclusions: The crude extract and aqueous fraction displayed potent non-selective cytotoxicity and noteworthy P-glycoprotein inhibition. These effects were attributed to solamargine. P-glycoprotein inhibitory activity was only present at concentrations higher than those inducing cytotoxicity, and thus does not appear to be the likely mechanism for the enhancement of doxorubicin's cytotoxicity. Preliminary results suggest that non-selective cytotoxicity may hinder drug development, however, further assessment of the mode of cell death is necessary to determine the route forward.
\end{abstract}

Keywords: Cancer, P-glycoprotein, Solanum aculeastrum, Solamargine, Solasonine, Steroidal alkaloids

\footnotetext{
* Correspondence: werner.cordier@up.ac.za

${ }^{1}$ Department of Pharmacology, School of Medicine, Faculty of Health

Sciences, University of Pretoria, P.O.Box X323, Pretoria, Arcadia 0007, South

Africa

Full list of author information is available at the end of the article
}

(c) The Author(s). 2018 Open Access This article is distributed under the terms of the Creative Commons Attribution 4.0 International License (http://creativecommons.org/licenses/by/4.0/), which permits unrestricted use, distribution, and reproduction in any medium, provided you give appropriate credit to the original author(s) and the source, provide a link to the Creative Commons license, and indicate if changes were made. The Creative Commons Public Domain Dedication waiver (http://creativecommons.org/publicdomain/zero/1.0/) applies to the data made available in this article, unless otherwise stated. 


\section{Background}

Cancer is a prominent contributor to worldwide mortality [1]. According to the World Health Organisation, 14. 1 million new cases of cancer were diagnosed in 2012, with 8.2 million cancer-related deaths reported between 2008 and 2012 [2]. In South Africa, more than 100,000 people are diagnosed with cancer annually, with prostate and breast cancer as the most frequently found [2].

Anticancer therapy includes options such as surgical interventions, radiation therapy and chemotherapy [1]. Due to cost, adverse effects [3, 4] and increasing resistance, the above mentioned therapeutic options are often subject to treatment failure [5]. Contributing resistance mechanisms include, among others, the over-expression of efflux transporters in cancer cells which aid in removing cytotoxins from the intracellular compartment [6]. The P-glycoprotein ( $\mathrm{P}$-gp) transporter has been implicated in such resistant cancer phenotypes [7]. P-gp is a $170 \mathrm{kDa}$ ATP-binding cassette membrane transporter which is expressed throughout the body [8]. Up-regulation of P-gp is associated with the majority of drug-resistant cancers, as it effluxes anticancer molecules such as doxorubicin, thus hindering its efficacy $[7,9]$.

Combination therapy has been suggested to counteract resistance, which allows for drugs to be used together at lower concentrations. This in turn may reduce side effects and potentially overcome resistance [10]. Doxorubicin is used alone or in combination to treat several cancers, solid tumours and soft tissue sarcomas [11]. However, with the increased frequency of cancer and lack of clinical effectivity of many anticancer drugs, novel treatments are sought [12]. Herbal remedies provide an ideal source of such chemical entities.

Complementary and alternative medicines are used worldwide for treatment of various diseases [13]. Numerous anticancer agents have been isolated from plants, or are derivatives thereof: vinblastine and vincristine (Catharanthus roseus); taxanes (Taxus canadensis); betulinic acid (Betula spp.), etoposide (Podophyllum spp.) and combretastatin (Combretum caffrum) [14-16]. Africa is a rich source of potentially bioactive phytochemicals, giving credence to the investigation of such herbal remedies against cancer.

The fruits of Solanum aculeastrum Dunal. (family Solanaceae), also known as the goat apple, are sometimes consumed by cancer patients as they believe it will be beneficial to treatment [17]. Literature concerning the anticancer activity of extracts is scarce, however, steroidal alkaloids such as solamargine have been shown to possess such properties $[18,19]$. The aim of the study was to assess the in vitro anticancer activity of alkaloidenriched fractions from $S$. aculeastrum fruits by determining its cytotoxicity, P-gp inhibition, and effect in combination with doxorubicin. Furthermore, the bioactive constituents was isolated and identified.

\section{Methods}

\section{Plant material}

Ripened fruits of $S$. aculeastrum were gifted from the Makana Botanical Gardens in Grahamstown (Eastern Cape, South Africa), where the identity was confirmed by Ms. Karin Cockburn. Specimens are available within the botanical gardens, while plant material is stored within the Department of Pharmacology as sectioned and powdered plant material. Fruits were cut and airdried at ambient temperature. Plant material was ground to a fine powder (Yellowline A10, Merck (Pty) Ltd) and stored in air-tight, amber containers until needed.

\section{Preparation of crude extract}

Ground plant material (150 g) was sonicated in $1.5 \mathrm{~L}$ methanol for $30 \mathrm{~min}$, after which it was agitated for $2 \mathrm{~h}$ on a shaker. The solution was incubated for an additional $16 \mathrm{~h}$ at $4{ }^{\circ} \mathrm{C}$. The supernatant was collected, and the marc re-extracted five more times. Supernatants were pooled, centrifuged at $500 \mathrm{~g}$ for $1 \mathrm{~min}$, vacuumfiltered $(0.2 \mu \mathrm{m}$ filters, Waters Corporation) and concentrated using in vacuo rotary evaporation (Büchi Rotovapor R-200, Büchi). Dried crystals were resuspended in distilled water $\left(\mathrm{dH}_{2} \mathrm{O}\right)$ and lyophilized (Freezone ${ }^{\bullet} 6$ Freeze Dry System, Labconco) to yield a dry, yellow powder $(17.98 \% \mathrm{w} / \mathrm{w})$.

\section{Preparation of alkaloid-enriched fractions}

Alkaloid-enriched fractions were prepared as described by Munari et al. [20] with modifications to the volumes used. Two organic fractions were obtained by sequential liquid-liquid extraction with diethyl ether and chloroform. The crude extract (26.72 g) was acidified with $2 \%$ acetic acid $(267.2 \mathrm{~mL})$ on a shaker for $2 \mathrm{~h}$. Diethyl ether (534.4 $\mathrm{mL}$ ) was added to the acidified mixture, shaken for $20 \mathrm{~min}$ and the organic phase siphoned off after separation. This procedure was repeated four times, and all diethyl ether fractions combined. After fractionation, the aqueous phase was fractionated with chloroform as described above. Organic fractions were clarified with anhydrous sodium sulphate $(10 \% w / v)$. The two organic fractions (diethyl ether $[8.98 \% w / w]$ and chloroform $[0$. $15 \% \mathrm{w} / \mathrm{w}]$ ) and the aqueous alkaloid-enriched fraction were concentrated using in vacuo rotary evaporation and lyophilisation, respectively. All samples were dissolved in dimethyl sulfoxide (DMSO). Aliquots $(20 \mathrm{mg} / \mathrm{mL})$ were stored at $-80{ }^{\circ} \mathrm{C}$ until needed.

\section{Test for the presence of steroidal alkaloids}

Samples $(20 \mu \mathrm{g})$ were spotted onto a C10 silica plate $(5 \times$ $10 \mathrm{~cm}$, Agilent Technologies South Africa) and developed in a mobile phase consisting of chloroform, acetone and methanol (4:4:2). Plates were visualized using ultraviolet 
light (UV, at 254 and $366 \mathrm{~nm}$ ), sprayed with Dragendorff's reagent and developed in an oven at $60^{\circ} \mathrm{C}$.

\section{Cellular assays \\ Cell maintenance}

The Caco-2, DU145, HepG2, MCF-7, MDA-MB-231, SK-Br3, 3 T3-L1, C2C12 and SC-1 cell lines were obtained from the American Tissue Culture Collection (ATCC), while the A2780 cell line was obtained from the European Collection of Authenticated Cell Cultures. The SH-SY5Y cell line was gifted from North-West University's Department of Pharmacology, which was originally purchased from the ATCC. The Ea.hy926 cell line was gifted by Dr. C Edgell.

Cells were grown in either Dulbecco's Modified Eagle Medium (DMEM; 3 T3-L1 pre-adipocytes, C2C12 myoblast, EA.hy926 hybrid endothelial, MCF-7 breast carcinoma, MDA-MB-231 breast adenocarcinoma cell lines), Eagle's Minimum Essential Medium (EMEM; Caco-2 colon carcinoma, HepG2 hepatocarcinoma, SC-1 mouse fibroblast cell lines), Hams F12 Nutrient Medium (Hams-F12, SH-SY5Y neuroblastoma) or Roswell Park Memorial Institute-1640 (RPMI-1640; A2780 ovarian carcinoma, DU145 prostate carcinoma, Sk-Br3 breast adenocarcinoma) supplemented with $10 \%$ foetal calf serum (FCS) and $1 \%$ penicillin/streptomycin at $37{ }^{\circ} \mathrm{C}$ in a humidified atmosphere of $5 \% \mathrm{CO}_{2}$. Adherent cells were harvested through trypsination and centrifugation at $200 \mathrm{~g}$ for $5 \mathrm{~min}$. Cells were counted using the trypan blue exclusion assay and resuspended at the desired concentration $\left(\mathrm{HepG} 2=2 \times 10^{5}\right.$ cells $/ \mathrm{mL} ; 3$ T3-L1, A2780, C2C12, Caco-2, DU145, EA.hy926, MCF-7, MDA-MB231, SC-1, Sk-BR-3 and SH-SY5Y $=1 \times 10^{5}$ cells $/ \mathrm{mL}$ ). Cells $(100 \mu \mathrm{L})$ were seeded into clear 96-well plates and allowed to attach overnight.

\section{Cytotoxicity evaluation}

The effect of the crude extract and fractions on cell density was determined using the sulforhodamine B (SRB) colourimetric assay as described by Vichai and Kirtikura [21], with minor modifications. Cells were exposed to $100 \mu \mathrm{L}$ FCS-free medium (negative control $[\mathrm{NC}])$, DMSO (0.5\%, vehicle control $[\mathrm{VC}])$, saponin (1\%, positive control $[\mathrm{PC}])$ or sample $(2,6.4,20,64$ and $200 \mu \mathrm{g} / \mathrm{mL})$ for 24 or $72 \mathrm{~h}$. Cells were fixed overnight at $4{ }^{\circ} \mathrm{C}$ with $50 \mu \mathrm{L}$ trichloroacetic acid (50\%). Plates were washed four times with tap water and allowed to dry at $40{ }^{\circ} \mathrm{C}$ in an oven. Fixed protein elements were stained with $100 \mu \mathrm{L}$ SRB $(0.057 \%$ in $1 \%$ acetic acid) and incubated for $30 \mathrm{~min}$. Plates were washed with $100 \mu \mathrm{L}$ acetic acid (1\%) thrice and allowed to dry. Bound dye was dissolved with $200 \mu \mathrm{L}$ Tris-base solution (10 mM, pH 10.5). Absorbance was measured at $510 \mathrm{~nm}$ (reference $630 \mathrm{~nm}$ ) using an ELX800UV plate reader (Bio-Tek
Instruments, Inc.). Four cell lines were selected for the remainder of the study based on the cytotoxicity evaluation: the two most susceptible cancerous cell lines (SH-SY5Y and SK-Br3), as well as one susceptible (EA.hy926) and one non-susceptible (C2C12) non-cancerous cell line.

\section{P-glycoprotein inhibition}

The rhodamine-123 accumulation assay was used to assess P-gp inhibitory activity according to Jia and Wasan [22] with modifications to volumes and incubation times. Cells were seeded as described in Section 2.5.1. and allowed to attach for $48 \mathrm{~h}$ in white 96-well plates. Wells were exposed to $100 \mu \mathrm{L}$ phosphate-buffered saline (PBS) (blank and NC), DMSO (VC, 0.5\%), samples (2, 6. 4, 20, 64 and $200 \mu \mathrm{g} / \mathrm{mL}$ ) or verapamil (PC; 2, 6.4 and $20 \mu \mathrm{M})$ prepared in PBS, and incubated for $1 \mathrm{~h}$ at $37^{\circ} \mathrm{C}$. After incubation, $40 \mu \mathrm{L}$ rhodamine- $123(10 \mu \mathrm{M})$ was added for $1 \mathrm{~h}$. Cells were washed twice with PBS and resuspended in $100 \mu \mathrm{L}$ PBS. Fluorescence was measured using a FLUOstar OPTIMA plate reader (BMG Labtech) at $485 \mathrm{~nm}$ (excitation) and $520 \mathrm{~nm}$ (emission). After measurement, cell density was assessed using the SRB assay to normalise data to avoid misinterpretation due to altered cell density. Data was blank-excluded, fluorescence intensity normalised to cell density and expressed as a fold change relative to the negative control.

\section{Isolation of active compound Bioassay-guided fractionation}

The most active fraction (aqueous alkaloid-enriched fraction) was subjected to high performance liquid chromatography (HPLC; Agilent 1200 HPLC System, Agilent Technologies South Africa) using acetonitrile and $\mathrm{dH}_{2} \mathrm{O}$ (gradient: $0-10 \%$ acetonitrile between 0 and $5 \mathrm{~min}$, to $100 \%$ at $30 \mathrm{~min}$, total run time: $35 \mathrm{~min}$ ) and a Sunfire C18 semi-preparative column $(150 \mathrm{~mm} \times 10 \mathrm{~mm}$, particle size: $10 \mu \mathrm{m})$. Samples $(25 \mathrm{mg} / \mathrm{mL})$ were repeatedly injected and fractionated into eleven sub-fractions collected every $2 \mathrm{~min}$. Each sub-fraction was reconstituted to the desired concentration in DMSO. Cytotoxicity and P-gp inhibition was assessed against the SK-Br3 breast carcinoma cell line at $50 \mu \mathrm{g} / \mathrm{mL}$. Sub-fractions 10 and 11 were most active, and thus further assessed.

\section{Isolation of active constituents by column and solid phase extraction chromatography}

Silica gel was mixed with chloroform and methanol (3:2) and poured into a cotton wool plugged glass column $(2.7 \times 50.5 \mathrm{~cm})$. The aqueous alkaloid-enriched fraction was dissolved in a hydromethanolic solution $\left(10 \% \mathrm{dH}_{2} \mathrm{O}\right)$, mixed with silica, left at room temperature to dry and loaded on top of the packed silica gel column. Subfractions were collected in glass tubes, monitored using 
TLC, and compared to sub-fractions 10 and 11 as reference. Similar sub-fractions were pooled together and further purified by solid phase extraction chromatography using a ISOLUTE flash $\mathrm{C} 18$ column with a mobile phase of acetonitrile and $\mathrm{dH}_{2} \mathrm{O}$ (starting at $100 \% \mathrm{dH}_{2} \mathrm{O}$, followed by $5 \%$ acetonitrile, then $10 \%$ acetonitrile and increasing to $100 \%$ acetonitrile in $10 \%$ increments). Major compounds co-eluted at $40 \%$ acetonitrile as a white-powder and were separated using preparative TLC (solvent system: methanol, ethyl acetate and acetone; 4:4:2) to afford compound 1 and compound 2 .

The identities of the isolated compounds were confirmed using Nuclear Magnetic Resonance (NMR, $600 \mathrm{MHz}$ VNMRS, Varian) and Ultra-Performance Liquid Chromatography Tandem Mass-Spectrometry (Synapt G1 UPLC-QTOF-HDMS system, Waters, USA) analysis. Compounds were analysed using different NMR techniques such as H-1-NMR, C-13-NMR, Heteronuclear Single Quantum Coherence (HSQC), Heteronuclear Multiple Bond Correlation (HMBC) and correlation spectroscopy (COSY) to accurately determine structural moieties. Mass Lynx 4.1 software was used for analysis of mass spectrometry data and the fragmentation patterns of the isolated compounds were identified using Waters MassFragment software (version 2.0.w.15).

\section{UPLC-TOF-MS fingerprinting of the crude extract and alkaloid-enriched fractions}

Samples $(20 \mathrm{mg} / \mathrm{mL})$ were subjected to UPLC-QTOFHDMS analysis in order to screen for major constituents. The relative abundance of the major compounds was compared between samples by equalising the intensity scale between chromatograms of different samples. The highest sample intensity was used as the scale standard for other chromatograms.

\section{Bioactivity}

Compounds 1 and $2(0.32,1,3.2,32$ and $50 \mu \mathrm{g} / \mathrm{mL})$ were assessed for cytotoxicity against the $\mathrm{C} 2 \mathrm{C} 12$, EA. hy29, SH-SY5Y and SK-Br3 cell lines after $72 \mathrm{~h}$ exposure. P-gp inhibitory activity was assessed in the SHSY5Y and EA.hy926 cell lines only. Only the most active compound was subjected to synergistic investigation with doxorubicin.

\section{Synergistic potential evaluation of the aqueous alkaloid- enriched fraction and active isolated compound in combination with doxorubicin}

The synergistic potential of the aqueous alkaloidenriched fraction and active compound in combination with doxorubicin was assessed using the method of Kars et al. [23]. The half maximal inhibitory concentration $\left(\mathrm{IC}_{50}\right)$ of the aqueous alkaloid-enriched fraction was reassessed, as well as the cytotoxicity of doxorubicin against the C2C12, EA.hy29, SH-SY5Y and SK-Br3 cell lines. The active isolated compound, aqueous alkaloidenriched fraction and doxorubicin was tested at two-, one-, half- and a quarter-fold the respective $\mathrm{IC}_{50}$ values in a checkerboard fashion.

Effects of the combination between doxorubicin and the extract/fractions were presented as a fractional inhibitory index (FIX):

$$
F I X=F I C(A)+F I C(B)
$$

A FIX value $<0.5$ is indicative of synergism, between 0 . $5-1$ as additive effect, between 1 and 2 as an indifferent effect and $>2$ as antagonism.

\section{Statistics}

All experiments were performed with technical and biological triplicates. Results were presented as the mean \pm SEM. Statistical analyses were done using GraphPad Prism 5.0. Non-linear regression was used to determine the $\mathrm{IC}_{50}$. Kruskal-Wallis analysis with a post-hoc Dunn's test was used to compare controls to samples. Significance was taken as $p<0.05$.

\section{Results}

Isolation and structural elucidation of steroidal alkaloids

Intense black and violet spots were observed for the crude extract and alkaloid-enriched fraction on TLC plates under short $(254 \mathrm{~nm})$ and long $(366 \mathrm{~nm})$-wavelength UV light, respectively. Orange spots were seen after spraying with Dragendorff's reagent. The aqueous alkaloid-enriched fraction was sub-fractionated into eleven fractions. Two major compounds were identified in sub-fractions 10 and 11, which were not visible under UV light, but appeared after vanillin-spraying.

Compound 1 appeared as white crystals. The structure of compound 1 was identified by H-1-NMR, C-13-NMR, 2-D data analysis. C-13-NMR revealed that compound 1 possesses an aglycone backbone related to a steroidal spirazolane-type alkaloid. Four quaternary carbons at chemical shifts $\left(\delta_{\mathrm{c}}\right.$ 's $) 38.2, \delta_{\mathrm{c}} 41.8 \mathrm{ppm}$ including one linked to oxygen and nitrogen at $\delta_{c} 99.6$ as well as one attached to a double bond at $\delta_{\mathrm{c}} 142.1$, nine methine groups at $\delta_{\mathrm{c}}$ 's $31.8,31.8,42.9,51.9,57.9,64.2,79.5,80.5$, 122.8 , ten methylene groups at $\delta_{\mathrm{c}}$ 's $22.2,30.9,31.1,32.9$, 33.1, 33.4, 38.7, 39.7, 41.2, $48.5 \mathrm{ppm}$ and four methyl groups at $\delta_{\mathrm{c}}$ 's $15.6,17.0,19.9,19.9 \mathrm{ppm}$ were observed (Table 1). An ether function with a trisaccharide moiety showing an anomeric carbon at $\delta_{\mathrm{c}} 100.6$ linked to the oxygen of C-3 at $\delta_{\mathrm{c}} 79.5$ was also present (Table 1 ). The 1D NMR chemical shifts of the trisaccharide moiety indicated the structure $O$-[ $\alpha$-L-rhamnopyranosyl- $(1 \rightarrow 2)$ $O$-[ $\alpha$-L-rhamnopyranosyl- $(1 \rightarrow 4)]-\beta-D$-glucopyranoside. The proton NMR showed four distinctive aglycone 
Table $1 \mathrm{H}-1$-NMR and C-13-NMR resonances of compound 1 compared to solamargine

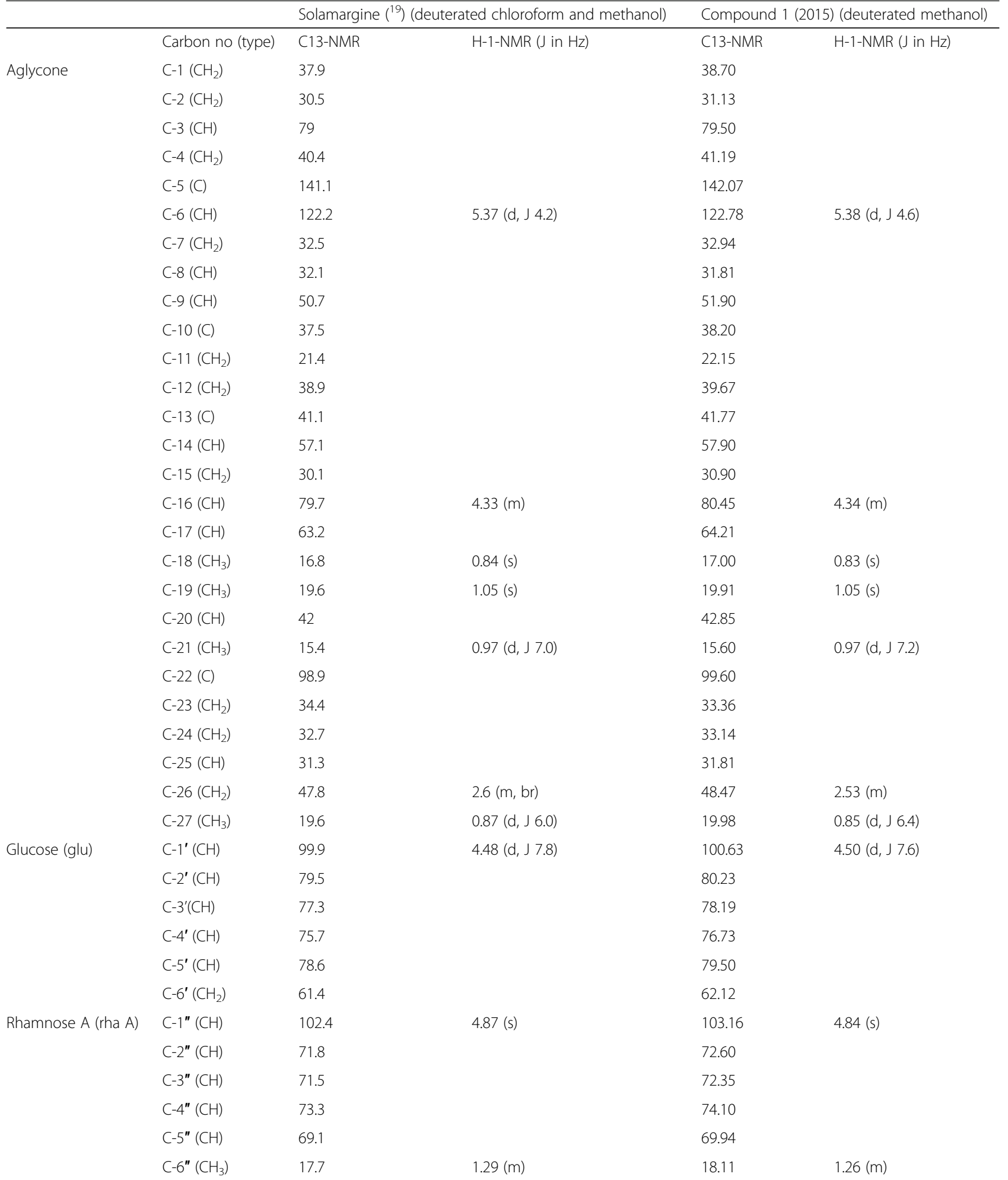


Table 1 H-1-NMR and C-13-NMR resonances of compound 1 compared to solamargine (Continued)

\begin{tabular}{|c|c|c|c|c|c|}
\hline \multirow{2}{*}{ Rhamnose B (rha B) } & \multirow[b]{2}{*}{$\mathrm{C}-1^{\prime \prime \prime}(\mathrm{CH})$} & \multicolumn{2}{|c|}{ Solamargine $\left({ }^{19}\right)$ (deuterated chloroform and methanol) } & \multicolumn{2}{|c|}{ Compound 1 (2015) (deuterated methanol) } \\
\hline & & 101.5 & $5.23(s)$ & 102.44 & $5.21(\mathrm{~s})$ \\
\hline & $\mathrm{C}-2^{\prime \prime \prime}(\mathrm{CH})$ & 71.6 & & 72.52 & \\
\hline & $\mathrm{C}-3^{\prime \prime \prime}(\mathrm{CH})$ & 71.3 & & 72.35 & \\
\hline & $\mathrm{C}-4^{\prime \prime \prime}(\mathrm{CH})$ & 73 & & 73.89 & \\
\hline & $\mathrm{C}-5^{\prime \prime \prime}(\mathrm{CH})$ & 70.1 & & 70.85 & \\
\hline & $\mathrm{C}-6^{\prime \prime \prime}\left(\mathrm{CH}_{3}\right)$ & 17.6 & $1.29(\mathrm{~m})$ & 18.0 & $1.26(\mathrm{~m})$ \\
\hline
\end{tabular}

methyls at $\delta_{\mathrm{c}} 0.83(3 \mathrm{H}, \mathrm{s}), 0.85(3 \mathrm{H}, \mathrm{d}, J$ [coupling constant] 6.4), $0.97(3 \mathrm{H}, \mathrm{d}, J 7.2)$ and $1.05(3 \mathrm{H}, \mathrm{s})$ (Table 1$)$. Two multiplets observed at $\delta_{\mathrm{c}} 1.26$ were attributable to 6-deoxyhexose methyls whereas a doublet at $\delta_{\mathrm{c}} 5.38$ with $J$ value of 4.6 could be attributed to an olefinic proton at position C-6. Four anomeric H-1-NMR resonances were observed at $\delta_{\mathrm{c}} 4.34(1 \mathrm{H}, \mathrm{m}), 4.50(1 \mathrm{H}, \mathrm{d}, J 7.6), 4.84(1 \mathrm{H}$, s) and $5.21(1 \mathrm{H}, \mathrm{s})$ (Table 1$)$. High resolution mass spectrometry (HRMS) data for compound 1 yielded the molecular formula $\mathrm{C}_{45} \mathrm{H}_{73} \mathrm{NO}_{15}$ with a molecular mass of $\mathrm{m} / \mathrm{z}$ (mass to charge ratio) $868.5077\left([\mathrm{M}+\mathrm{H}]^{+}, 100 \%\right)$ which was identified as the steroidal alkaloid, solamargine (Fig. 1).

Extensive evaluation of the similarities in characteristic signals of the H-1-NMR, C-13-NMR and 2-D NMR for compound 2 revealed that it was like compound 1 . The structure included an aglycone backbone attached to a trisaccharide moiety. However, differences were present in the trisaccharide sugar moiety in which a O-[ $\alpha-\mathrm{L}-$ rhamnopyranosyl- $(1 \rightarrow 2)-\mathrm{O}$-[b-glucopyranosyl- $(1 \rightarrow 3)$ ]- $\beta$-D-galactopyranoside structure was observed. HRMS data for compound 2 yielded the molecular formula
$\mathrm{C}_{45} \mathrm{H}_{73} \mathrm{NO}_{16}$ with molecular weight peak at $m / z 884.5205$ $\left([\mathrm{M}+\mathrm{H}]^{+}, 100 \%\right)$ which was identified as the steroidal alkaloid solasonine (Fig. 1). The mass difference between solasonine and solamargine is consistent with the additional hydroxyl group seen in solasonine's structure.

UPLC-QTOF-HDMS analysis of the crude extract and alkaloid-enriched fractions revealed that solamargine and solasonine with $m / z^{\prime} s$ of 868.4987 and $884.4989\left([\mathrm{M}+\mathrm{H}]^{+}\right.$, $100 \%)$, respectively, were the two major constituents. Although there were similarities in composition between samples, the concentration of major compounds differed. The crude extract and aqueous alkaloid-enriched fraction had a significantly higher abundance of solamargine and solasonine when compared to the chloroform and ether fractions.

\section{Cytotoxicity}

Samples were cytotoxic in cancerous (A2780, Caco-2, DU-145, HepG2, MCF-7, MDA-MB-231, SH-SY5Y and SK-Br3) and non-cancerous (3 T3-L1, C2C12, EA.hy.926 and SC-1) cell lines (Table 2). The crude extract and

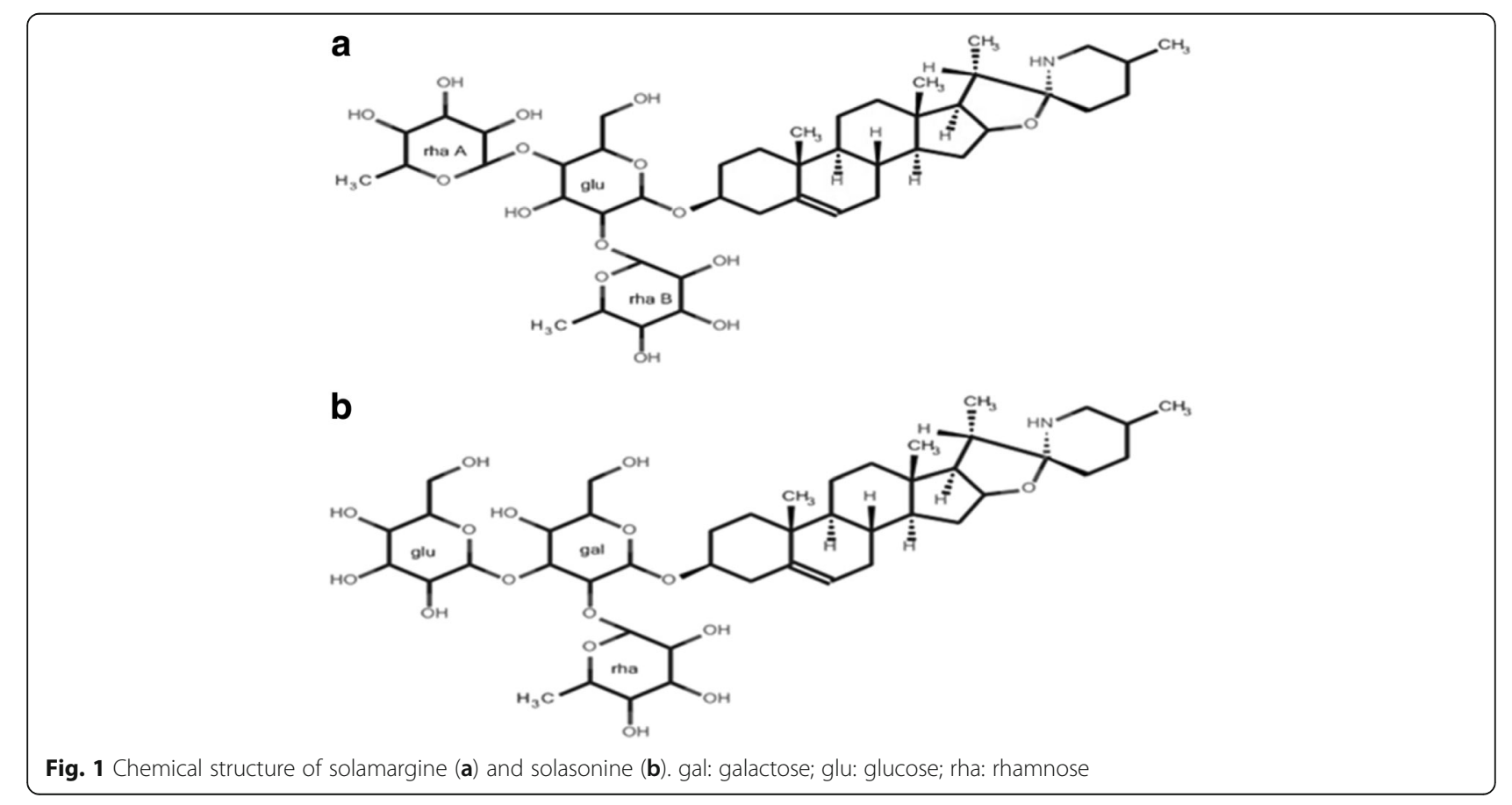


Table 2 Cytotoxicity of the crude extract, aqueous alkaloid-enriched fraction and solamargine as described by their $I_{50}$ values in a panel of cancerous and non-cancerous cell lines

\begin{tabular}{|c|c|c|c|c|c|c|c|c|c|c|c|c|}
\hline \multirow[b]{3}{*}{$\begin{array}{l}\text { Extract/ } \\
\text { fraction }^{a}\end{array}$} & \multicolumn{12}{|c|}{$\mathrm{IC}_{50} \pm \mathrm{SEM}$} \\
\hline & \multicolumn{8}{|c|}{ Cancerous cell lines } & \multicolumn{4}{|c|}{ Non-cancerous cell lines } \\
\hline & A2780 & Caco-2 & DU-145 & HepG2 & MCF-7 & $\begin{array}{l}\text { MDA-MB- } \\
231\end{array}$ & SH-SY5Y & SK-Br3 & 3 T3-L1 & $\mathrm{C} 2 \mathrm{C} 12$ & EA.hy.926 & SC-1 \\
\hline Crude $24 \mathrm{~h}^{\mathrm{a}}$ & $\begin{array}{l}34.73 \pm \\
1.07\end{array}$ & $\begin{array}{l}36.46 \pm \\
1.20\end{array}$ & $\begin{array}{l}74.33 \pm \\
1.14\end{array}$ & $\begin{array}{l}9.44 \pm \\
1.11\end{array}$ & $\begin{array}{l}44.35 \pm \\
1.06\end{array}$ & $26.87^{*}$ & $\begin{array}{l}19.10 \pm \\
1.07\end{array}$ & $\begin{array}{l}33.25 \pm \\
1.10\end{array}$ & $\begin{array}{l}37.24 \pm \\
1.34\end{array}$ & $\begin{array}{l}93.41 \pm \\
1.08\end{array}$ & $\begin{array}{l}3.88 \pm \\
1.07\end{array}$ & $\begin{array}{l}28.73 \pm \\
1.09\end{array}$ \\
\hline Crude $72 \mathrm{~h}^{\mathrm{a}}$ & $32.88^{*}$ & $\begin{array}{l}24.40 \pm \\
1.13\end{array}$ & $\begin{array}{l}47.11 \pm \\
1.18\end{array}$ & $\begin{array}{l}7.04 \pm \\
1.08\end{array}$ & $\begin{array}{l}27.94 \pm \\
1.11\end{array}$ & $24.00^{*}$ & $\begin{array}{l}12.97 \pm \\
1.07\end{array}$ & $\begin{array}{l}20.11 \pm \\
1.08\end{array}$ & $\begin{array}{l}19.55 \pm \\
1.23\end{array}$ & $\begin{array}{l}91.18 \pm \\
1.13\end{array}$ & $\begin{array}{l}2.79 \pm \\
1.55\end{array}$ & $\begin{array}{l}23.07 \pm \\
1.10\end{array}$ \\
\hline $\begin{array}{l}\text { Aqueous } 24 \\
\mathrm{~h}^{\mathrm{a}}\end{array}$ & $31.45^{*}$ & $\begin{array}{l}50.37 \pm \\
1.26\end{array}$ & $\begin{array}{l}46.53 \pm \\
1.21\end{array}$ & $\begin{array}{l}40.02 \pm \\
1.08\end{array}$ & $\begin{array}{l}31.91 \pm \\
1.06\end{array}$ & $28.05^{*}$ & $29.11 \pm *$ & $29.24^{*}$ & $\begin{array}{l}21.95 \pm \\
1.50\end{array}$ & $>100$ & $\begin{array}{l}16.45 \\
\pm 1.06\end{array}$ & $\begin{array}{l}19.89 \pm \\
1.09\end{array}$ \\
\hline $\begin{array}{l}\text { Aqueous } \\
72 \mathrm{~h}^{\mathrm{a}}\end{array}$ & $29.81^{*}$ & $\begin{array}{l}25.21 \pm \\
1.12\end{array}$ & $34.08^{*}$ & $\begin{array}{l}20.66 \pm \\
1.10\end{array}$ & $\begin{array}{l}25.49 \pm \\
1.13\end{array}$ & $26.11^{*}$ & $\begin{array}{l}17.21 \pm \\
1.15\end{array}$ & $\begin{array}{l}18.81 \pm \\
1.14\end{array}$ & $\begin{array}{l}12.89 \pm \\
1.23\end{array}$ & $\begin{array}{l}62.00 \pm \\
1.22\end{array}$ & $\begin{array}{l}9.35 \pm \\
1.08\end{array}$ & $\begin{array}{l}21.10 \pm \\
1.08\end{array}$ \\
\hline $\begin{array}{l}\text { Solamargine } \\
72 \mathrm{~h}^{\mathrm{b}}\end{array}$ & $x$ & $x$ & $x$ & $x$ & $x$ & $x$ & $\begin{array}{l}15.62 \pm \\
1.45\end{array}$ & $\begin{array}{l}18.59 \pm \\
1.13\end{array}$ & $x$ & $\begin{array}{l}20.25 \pm \\
1.08\end{array}$ & $\begin{array}{l}8.30 \pm \\
1.12\end{array}$ & $x$ \\
\hline \multicolumn{13}{|l|}{ P-gp inhibitor } \\
\hline $\begin{array}{l}\text { Verapamil } \\
24 \mathrm{~h}^{\mathrm{b}}\end{array}$ & $\begin{array}{l}93.48 \pm \\
1.05\end{array}$ & $>100$ & $>100$ & $\begin{array}{l}18.72 \pm \\
1.08\end{array}$ & $>100$ & $>100$ & $>100$ & $>100$ & $>100$ & $>100$ & $\begin{array}{l}31.55 \pm \\
1.12\end{array}$ & $>100$ \\
\hline $\begin{array}{l}\text { Verapamil } \\
72 \mathrm{~h}^{\mathrm{b}}\end{array}$ & $\begin{array}{l}65.75 \pm \\
1.06\end{array}$ & $>100$ & $>100$ & $\begin{array}{l}8.34 \pm \\
1.08\end{array}$ & $\begin{array}{l}46.76 \pm \\
1.14\end{array}$ & $47.5 \pm 1.09$ & $>100$ & $\begin{array}{l}41.92 \pm \\
1.09\end{array}$ & $\begin{array}{l}79.22 \pm \\
1.21\end{array}$ & $>100$ & $\begin{array}{l}5.69 \pm \\
1.11\end{array}$ & $\begin{array}{l}60.01 \pm \\
1.16\end{array}$ \\
\hline
\end{tabular}

* Ambiguity in data points (GraphPad 5.0 software could not predict SEM due to steepness of dose-response curve) a presented in $\mu \mathrm{g} / \mathrm{mL}$

Bpresented in $\mu \mathrm{M}$

${ }^{x}$ Not tested on mentioned cell line

aqueous alkaloid-enriched fraction displayed noteworthy $(<30 \mu \mathrm{g} / \mathrm{mL})$ and moderate-to-low cytotoxicity ( $>30 \mu \mathrm{g} /$ $\mathrm{mL}$ ) after $72 \mathrm{~h}$ exposure (Table 2). In most cell lines, cytotoxicity was evident as early as $24 \mathrm{~h}$ exposure, which either plateaued or decreased (1-to-2-fold increase) after $72 \mathrm{~h}$ exposure. Variable cytotoxicity towards noncancerous cell lines was observed, with $\mathrm{IC}_{50}$ values from 3 . 88 to $93.41 \mu \mathrm{g} / \mathrm{mL}$ and 2.79 to $91.18 \mu \mathrm{g} / \mathrm{mL}$ after $24 \mathrm{~h}$ and $72 \mathrm{~h}$ exposure, respectively. The chloroform and diethyl ether fractions had negligible cytotoxicity. The aqueous alkaloid-enriched fraction had a potent dosedependent effect on the SH-SY5Y $\left(\mathrm{IC}_{50}=17.21 \mu \mathrm{g} /\right.$ $\mathrm{mL}), \mathrm{Sk}-\mathrm{Br} 3\left(\mathrm{IC}_{50}=18.81 \mu \mathrm{g} / \mathrm{mL}\right)$ and HepG2 $\left(\mathrm{IC}_{50}=\right.$ $20.66 \mu \mathrm{g} / \mathrm{mL}$, Table 2) cell lines, but displayed low cytotoxicity in the $\mathrm{C} 2 \mathrm{C} 12\left(\mathrm{IC}_{50}=62.00 \mu \mathrm{g} / \mathrm{mL}\right)$ cell line after $72 \mathrm{~h}$ exposure. The EA.hy926 cell line was most susceptible to the aqueous alkaloid-enriched fraction with an $\mathrm{IC}_{50}$ of $9.35 \mu \mathrm{g} / \mathrm{mL}$ after $72 \mathrm{~h}$, with a narrow cytotoxic range.

Sub-fractions 10 and 11 from the aqueous alkaloidenriched fraction displayed potent cytotoxicity ( 91\%) at $50 \mu \mathrm{g} / \mathrm{mL}$ in the SK-Br3 cell line. Bioactivity-guided fractionation and isolation procedures identified solamargine as the bioactive constituent. Solamargine induced dose-dependent cytotoxicity in the SH-SY5Y and SK-Br3 cell lines with $\mathrm{IC}_{50}$ values of $15.62 \mu \mathrm{M}$ (13. $54 \mu \mathrm{g} / \mathrm{mL})$ and $18.59 \mu \mathrm{M}(16.12 \mu \mathrm{g} / \mathrm{mL})$ after $72 \mathrm{~h}$ incubation, respectively (Table 2). Solasonine was not cytotoxic $\left(\mathrm{IC}_{50}>56.63 \mu \mathrm{M}\right.$ or $\left.50 \mu \mathrm{g} / \mathrm{mL}\right)$.

\section{P-glycoprotein inhibition}

The crude extract and the aqueous alkaloid-enriched fraction induced dose-dependent P-gp inhibition (2.87 to 21 . 2-fold) at $100 \mu \mathrm{g} / \mathrm{mL}$ (Fig. $2 \mathrm{~A}$ and D). The chloroform and diethyl ether fraction displayed poor P-gp inhibition (1.12 to 1.63 -fold). The diethyl ether, chloroform and aqueous alkaloid-enriched fractions showed the greatest inhibitory potential towards the SH-SY5Y cell line (Fig. 2B to 2D) with inhibition of $1.26,1.64$ and 21.21 -fold at $100 \mu \mathrm{g} / \mathrm{mL}$, respectively. The fractions exhibited the lowest activity towards the $\mathrm{C} 2 \mathrm{C} 12$ cell line with inhibitory values of $1.13,1$. 27 and 2.87 -fold at $100 \mu \mathrm{g} / \mathrm{mL}$, respectively. The aqueous alkaloid-enriched fraction displayed inhibitory activity across all cell lines, with values of 2.82 to 21.21 -fold at $100 \mu \mathrm{g} / \mathrm{mL}(p<0.001)$. The P-gp inhibition exhibited by the crude extract and aqueous alkaloid-enriched fraction was similar (5.89 to 18.88 -fold at $100 \mu \mathrm{g} / \mathrm{mL}[p<0.001]$ ). Significant $(p<0.05$ and 0.001$)$ but low P-gp inhibition was induced by the chloroform fraction in the SH-SY5Y cancerous cell line (Fig. 2C) with an inhibitory value of 1 . 64-fold at $100 \mu \mathrm{g} / \mathrm{mL}$. The diethyl ether fraction displayed low but significant $(p<0.01)$ inhibition in the EA.hy926 cell line of 1.47 -fold at $100 \mu \mathrm{g} / \mathrm{mL}$. No significant activity was noted for any other cell line tested.

Solamargine caused significant $(p<0.05$ and $p<0.001)$ dose-dependent P-gp inhibition in the SH-SY5Y cancerous cell line (Fig. 3A) with 5.07-fold activity at $36.9 \mu \mathrm{M}$ $(32 \mu \mathrm{g} / \mathrm{mL})$ and 9.10 -fold activity at $57.7 \mu \mathrm{M}(50 \mu \mathrm{g} /$ $\mathrm{mL})$. However, the effect was 3.95 -fold less when 


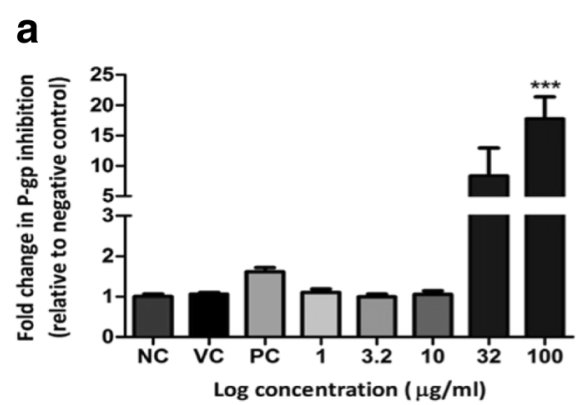

C

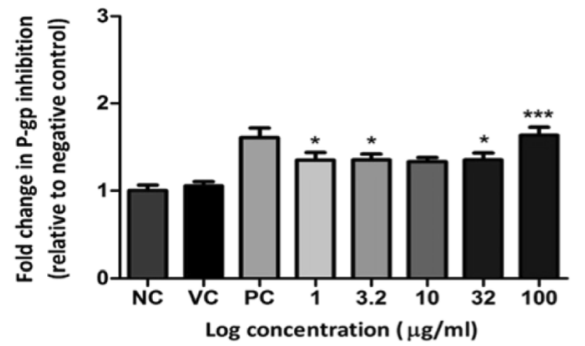

b

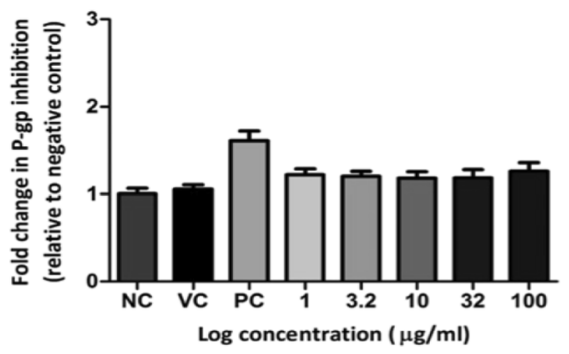

d

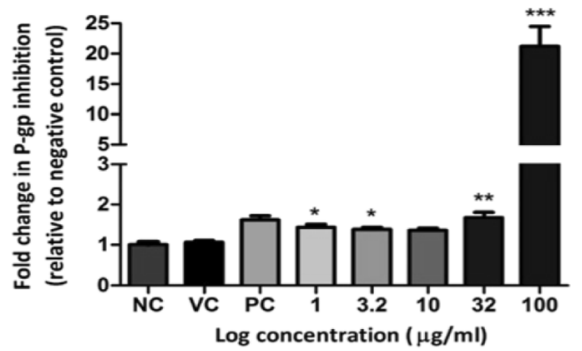

Fig. 2 P-gp inhibitory potential in the SH-SY5Y neuroblastoma cell line when exposed to the a) crude extract, $\mathbf{b}$ ) diethyl ether fraction, $\mathbf{c}$ ) chloroform fraction and d) aqueous alkaloid-enriched fraction. PC: verapamil $(1 \mu \mathrm{M}){ }^{*} p<0.05,{ }^{* *} p<0.01,{ }^{* * *} p<0.001$

compared to the aqueous alkaloid-enriched fraction (13. 05 -fold) at $50 \mu \mathrm{g} / \mathrm{mL}$ (Fig. 3A). Solamargine inhibited Pgp more in the EA.hy926 (13.81-fold) non-cancerous cell line when compared to the SH-SY5Y (9.05-fold) cancerous cell line at $57.70 \mu \mathrm{M}(50 \mu \mathrm{g} / \mathrm{mL})$. Solasonine did not inhibit P-gp activity (Fig. 3B).

\section{Synergistic potential of the aqueous alkaloid-enriched fraction and solamargine with doxorubicin}

A dose-dependent decrease in cell density was observed after exposure to doxorubicin, with more selectivity towards cancerous cell lines (Table 3). SH-SY5Y cells were most susceptible to doxorubicin ( $\mathrm{IC}_{50}$ of $56.60 \mathrm{nM}$ ). No synergistic effects were observed between doxorubicin and the aqueous alkaloid-enriched fraction or solamargine (Table 3). Additive effects were observed in the SH-SY5Y cell line for the doxorubicin combinations with the aqueous alkaloid-enriched fraction (FIX value $=0.71$ ) and solamargine (FIX value $=0.51$ ). Additive effects were also observed in the SK-Br3 and EA.hy926 cell lines when exposed to the combination with solamargine (FIX value $=0.66$ ) and the aqueous alkaloid-enriched fraction (FIX value $=0.94$ ), respectively. In contrast, antagonistic effects were observed in the $\mathrm{C} 2 \mathrm{C} 12$ cell line when exposed to combinations with the aqueous alkaloid-enriched fraction (FIX value $=2.10$ ) and solamargine (FIX value $=2.53)$. Indifferent effects were noted when the SK-Br-3 and EA.hy926 cell lines were exposed to the combination with the aqueous alkaloidenriched fraction and solamargine, respectively (Table 3, FIX values: $>1$, however $<2$ ).

\section{Discussion}

Steroidal alkaloids were positively identified in the crude extract and alkaloid-enriched fractions using both UV
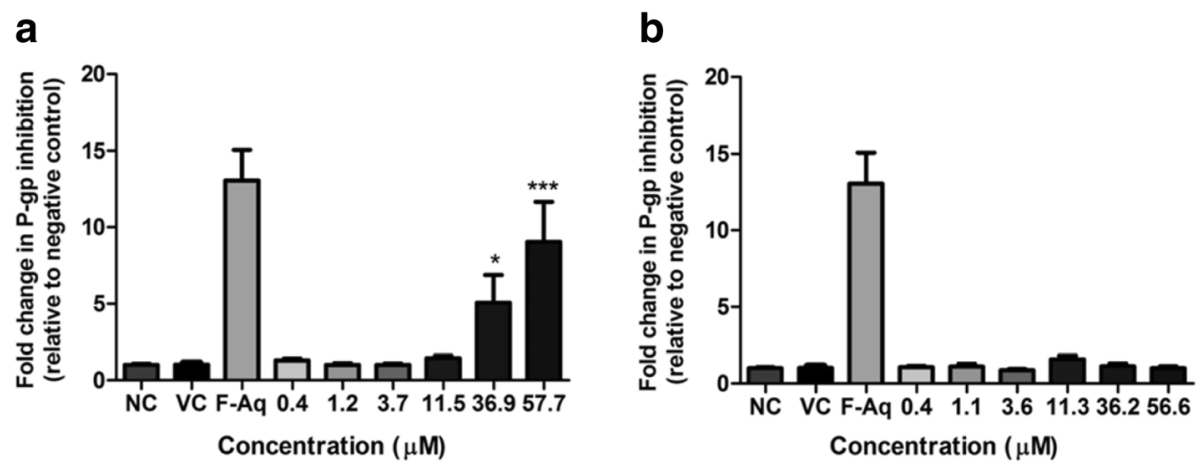

Fig. 3 P-gp inhibitory potential of solamargine (a) and solasonine (b) against the SH-SY5Y neuroblastoma cell line. ${ }^{*} p<0.05$, ${ }^{* * *} p<0.001$ 
Table 3 Synergistic potential of solamargine and the aqueous alkaloid-enriched fraction as described by their FIX values in a panel of cancerous and non-cancerous cell lines

\begin{tabular}{|c|c|c|c|c|c|c|c|c|}
\hline \multirow{3}{*}{$\begin{array}{l}\text { Cell type } \\
\text { Cell line } \\
\text { Compound/Fraction }\end{array}$} & \multicolumn{4}{|l|}{ Cancerous } & \multicolumn{4}{|c|}{ Non-cancerous } \\
\hline & \multicolumn{2}{|l|}{ SH-SY5Y } & \multicolumn{2}{|l|}{ SK-Br3 } & \multicolumn{2}{|l|}{$\mathrm{C} 2 \mathrm{C} 12$} & \multicolumn{2}{|l|}{ EA.hy926 } \\
\hline & Solamargine & $\begin{array}{l}\text { Aqueous } \\
\text { alkaloid- } \\
\text { enriched } \\
\text { fraction }\end{array}$ & Solamargine & $\begin{array}{l}\text { Aqueous } \\
\text { alkaloid- } \\
\text { enriched } \\
\text { fraction }\end{array}$ & Solamargine & $\begin{array}{l}\text { Aqueous } \\
\text { alkaloid- } \\
\text { enriched } \\
\text { fraction }\end{array}$ & Solamargine & $\begin{array}{l}\text { Aqueous } \\
\text { alkaloid- } \\
\text { enriched } \\
\text { fraction }\end{array}$ \\
\hline $\begin{array}{l}{ } C_{50} \text { of }(A)\left[I_{50}\right. \\
\text { sample }+ \text { doxorubicin } \\
(\mu \mathrm{M} \text { or } \mu \mathrm{g} / \mathrm{mL})]\end{array}$ & 3.4 & 7.39 & 4.3 & 11.18 & 30.77 & 15.7 & 5.5 & 2.62 \\
\hline $\begin{array}{l}\text { IC } C_{50} \text { of }(\mathrm{B}) \\
{\left[\mathrm{I} \mathrm{C}_{50} \text { doxorubicin + sample }(\mathrm{nM})\right]}\end{array}$ & 16.27 & 24.22 & 40.83 & 47.48 & 149.9 & 140.7 & 213.4 & 220 \\
\hline $\begin{array}{l}\mathrm{IC}_{50}(\mathrm{~A}) \text { [Solamargine }(\mu \mathrm{M}) \text { or } \\
\text { aqueous alone }(\mu \mathrm{g} / \mathrm{mL})]\end{array}$ & 15.62 & 26.5 & 18.59 & 19.7 & 20.25 & 13.7 & 8.3 & 7.3 \\
\hline $\mathrm{IC}_{50}$ (B) [doxorubicin alone $\left.(\mathrm{nM})\right]$ & 56.6 & 56.6 & 94.1 & 94.1 & 148.5 & 148.5 & 381.6 & 381.6 \\
\hline $\mathrm{FIC} \mathrm{(A)}$ & 0.22 & 0.28 & 0.23 & 0.57 & 1.52 & 1.15 & 0.66 & 0.36 \\
\hline $\mathrm{FIC}(\mathrm{B})$ & 0.29 & 0.43 & 0.43 & 0.5 & 1.01 & 0.95 & 0.56 & 0.58 \\
\hline FIX value & 0.51 & 0.71 & 0.66 & 1.07 & 2.53 & 2.1 & 1.22 & 0.94 \\
\hline Result & $\begin{array}{l}\text { Additive } \\
\text { effect }\end{array}$ & $\begin{array}{l}\text { Additive } \\
\text { effect }\end{array}$ & $\begin{array}{l}\text { Additive } \\
\text { effect }\end{array}$ & $\begin{array}{l}\text { Indifferent } \\
\text { effect }\end{array}$ & $\begin{array}{l}\text { Antagonistic } \\
\text { effect }\end{array}$ & $\begin{array}{l}\text { Antagonistic } \\
\text { effect }\end{array}$ & $\begin{array}{l}\text { Indifferent } \\
\text { effect }\end{array}$ & $\begin{array}{l}\text { Additive } \\
\text { effect }\end{array}$ \\
\hline
\end{tabular}

light and Dragendorff's reagent. Dragendorff's reagent is known to produce orange spots when reacting with alkaloids [24, 25]. Literature supports the presence of such alkaloids in S. aculeastrum [26]. The two most prominent steroidal alkaloids, solamargine (compound 1) and solasonine (compound 2), were isolated. Structural analysis was found to compare well with literature $[19,27]$. According to literature, more than 100 Solanum spp., including $S$. aculeastrum, contain solamargine and solasonine [28]. Other compounds isolated from $S$. aculeastrum include the steroidal alkaloids, solaculine A, solasodine and tomatidine $[19,26]$. Solanopubamine and solanidine have also been noted in other Solanum spp. [29, 30].

Both the crude extract and aqueous alkaloid-enriched fraction were highly cytotoxic in the panel of cell lines. A mixture of concentration- and time-dependent cytotoxicity was observed. A few isolated studies have assessed the cytotoxicity of $S$. aculeastrum, but not as broad as in the present study. Koduru et al. [17] reported that a methanol fruit extract displayed a narrow cytotoxic range, with an $\mathrm{IC}_{50}$ of $17.8 \mu \mathrm{g} / \mathrm{mL}$ in the MCF7 cell line [17]. Although the present study displayed greater cytotoxicity $\left(\mathrm{IC}_{50}=10.14 \mu \mathrm{g} / \mathrm{mL}\right)$, a narrow cytotoxic range was also observed. Other Solanum species, such as $S$. nigrum and $S$. incanum, have also been shown to be cytotoxic [31, 32]. S. incanum has been shown to induce both an antiproliferative and cytotoxic effect via cell cycle arrest and apoptosis [32].

The cytotoxicity observed for solamargine in the present study is similar to that described in literature (between 5.28 to $21.03 \mu \mathrm{M}$ [4.58 to $18.23 \mu \mathrm{g} / \mathrm{mL}$ ]) [20]. Solamargine alters cell morphology, induce chromatin condensation, and fragment DNA in hepatoma (Hep3B) cells, suggesting a pro-apoptotic effect [33]. Apoptosis appears to occur via intrinsic and extrinsic apoptotic pathways in breast cancer cells [34]. Furthermore, solamargine induces extracellular signal-regulated protein kinases 1 and 2 (ERK1/2) with downstream cytotoxicity in human lung cancer [35]. Solamargine may also deter metastatic effects in cancer by reducing its invasive and migratory potential [36]. In the present study, solasonine was not cytotoxic. Conflicting results have been reported, which either support [37] or contradict [20] the current findings. Conformational changes in solasonine's molecular structure could account for the differences in cytotoxicity [38].

The non-selective cytotoxicity observed for the samples render the extracts and solamargine as poor candidates for further drug development, unless structural alterations could improve its selectivity for cancerous cell lines. Similar results were reported by Munari et al. [20], where an ethanol extract from S. lycocarpum fruits, as well as solamargine, displayed antiproliferative effects towards human and Chinese hamster lung fibroblast cell lines [20].

The crude extract and aqueous alkaloid-enriched fraction displayed prominent P-gp inhibitory activity, which could be ascribed to the presence of solamargine, however, other phytochemcials cannot be excluded. The Pgp inhibitory activity was only seen at concentrations greater than that inducing cytotoxic effects, and also displayed non-selective inhibition. Literature is scarce regarding P-gp inhibitory activity of Solanum spp. An ethanol extract from $S$. trilobatum was found to induce 
significant $(p<0.05)$ inhibition when compared to verapamil, however, only at $300 \mu \mathrm{g} / \mathrm{mL}$ [39]. This species also contains solamargine and solasodine, which are known to diminish P-gp function [40]. Solamargine has been shown to decrease MDR1 mRNA expression [41], and reduce P-gp expression [40]. P-gp expression has been linked to the structural integrity of cells [42], suggesting that the loss of cellular morphology may contribute to the inhibition observed. Other steroidal alkaloids, such as tomatidine and cyclopamine, have also been found to inhibit P-gp [42]. Steroidal alkaloids may act as noncompetitive inhibitors of P-gp. Active transport of compounds across the cellular membrane occurs at two distinct sites ( $H$ and $R)$ in the transmembrane region [43]. Since steroidal alkaloids are small compounds, which possess a nitrogen atom and have a planar structure, they diffuse rapidly into cells. As such, compounds may interact easily with membrane carriers or transporters [43], decreasing activity.

Solamargine was shown to enhance the cytotoxic effect of doxorubicin in both SH-SY5Y and SK-Br3 cancerous cell lines. This potentiated response was not observed in non-cancerous cell lines, which suggests solamargine may be effective in improving treatment regimens for both neuroblastoma and certain breast cancers. As previously mentioned, in the present study P-gp inhibition only occurred at cytotoxic concentrations, thus enhancement of doxorubicin cytotoxic effects through P-gp inhibition seems improbable at the concentrations tested. The additive effects observed in the present study may indicate that the samples and doxorubicin target the similar pathways. Both doxorubicin and the samples have been proposed to mediate cell death via apoptosis. An antagonistic interaction would, such as that seen in the $\mathrm{C} 2 \mathrm{C} 12$ cell line, suggests conflicting mechanisms on the same pathway [44]. Other species of Solanum have also been shown to provide conflicting combinational effects. For example, both synergistic and antagonistic interactions have been described for extracts of $S$. nigrum $[45,46]$. The bioactive constituents are proposed to be steroidal alkaloids, such as solamargine [47], which is known to increase the cytotoxicity of anticancer drugs, such as cisplatin [48]. Chaconine and solanine [49], as well as other P-gp inhibitors $[50,51]$ display similar effects.

\section{Conclusions}

The crude extract, as well as the aqueous alkaloid-enriched fraction, displayed noteworthy cytotoxicity and P-gp inhibition towards both cancerous and non-cancerous cell lines. Solamargine was found to be responsible for potent, nonselective cytotoxicity and P-gp inhibition. Solamargine and the aqueous alkaloid-enriched fraction enhanced doxorubicin's cytotoxicity through additive effects in select cell lines, whereas having indifferent and antagonistic responses in others. P-gp inhibition only occurred at concentrations higher than those eliciting cytotoxicity, suggesting an alternative mechanism underlying its additive effect with doxorubicin. Due to the non-selective bioactivity, further mechanistic studies are required to address the preliminary results so that drug development viability can be assessed.

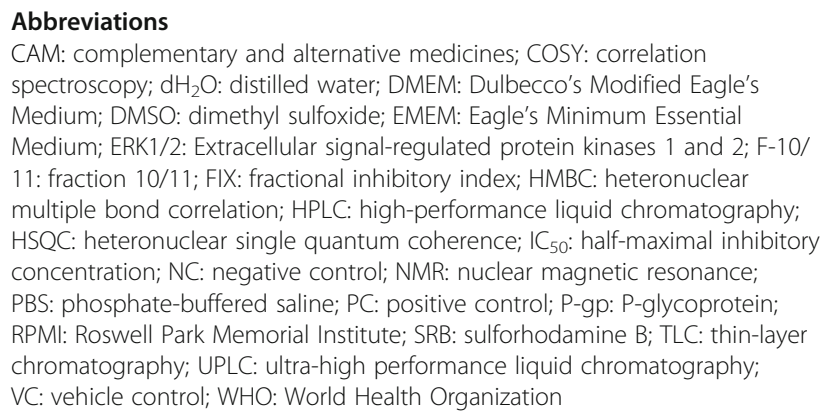

\section{Acknowledgements}

The authors would like to acknowledge the National Research Foundation for funding, Dr. C Edgell for supplying the EA.hy296 endothelial hybrid cell line, Karin Cockburn for provision of the plant material and Prof AD Cromarty for technical advice.

Availability of data and materials

Data is stored in the Department of Pharmacology of the University of

Pretoria, and can be requested from the corresponding author.

\section{Authors' contributions}

TB conducted all experimental work, with the assistance of GF, PS and TM for chromatographical elucidation and review of the manuscript. WC conceptualised the project and reviewed the manuscript and experimental data. VS reviewed the manuscript and co-supervised the project. All authors have read and approved the manuscript.

Ethics approval and consent to participate

Ethical approval for the use of commercial cell lines was obtained from the Research Ethics Committee of the University of Pretoria (\#167/2015).

\section{Competing interests}

The authors declare that they have no competing interests.

\section{Publisher's Note}

Springer Nature remains neutral with regard to jurisdictional claims in published maps and institutional affiliations.

\section{Author details}

${ }^{1}$ Department of Pharmacology, School of Medicine, Faculty of Health Sciences, University of Pretoria, P.O.Box X323, Pretoria, Arcadia 0007, South Africa. ${ }^{2}$ Biosciences Division, Council of Scientific and Industrial Research, Pretoria, South Africa. ${ }^{3}$ Department of Biochemistry, University of Johannesburg, Auckland Park, Johannesburg, South Africa.

Received: 6 June 2017 Accepted: 17 April 2018

Published online: 02 May 2018

\section{References}

1. Siegel R, DeSantis C, Virgo K, Stein K, Mariotto A, Smith T, Cooper D, Gansler T, Lerro C, Fedewa S, Lin C. Cancer treatment and survivorship statistics. CA Cancer J Clin. 2012;62:220-41.

2. GLOBOCAN, 2012. Cancer fact sheets. http://globocan.iarc.fr/Pages/fact_ sheets_cancer.aspx. Accessed 01.05.14.

3. Royal S, Smeaton L, Avery AJ, Hurwitz B, Sheikh A. Interventions in primary care to reduce medication related adverse effects and hospital admissions: systematic review and meta-analysis. Qual Saf Health Care. 2006;15:23-31. 
4. Meropol NJ, Schrag D, Smith TJ, Mulvey TM, Langdon RM Jr, Blum D, Ubel PA. American Society of Clinical Oncology guidance statement: the cost of cancer care. J Clin Oncol. 2009;27:3868-74.

5. Bock $C$, Lengauer T. Managing drug resistance in cancer: lessons from HIV therapy. Nat Rev Cancer. 2012;12:494-501.

6. Liu FS. Mechanisms of chemotherapeutic drug resistance in cancer therapya quick review. Taiwan J Obstet Gynecol. 2009;48:239-44.

7. Borst P, Oude ER. Mammalian ABC transporters and disease. Annu Rev Biochem. 2002;71:537-92.

8. Rautio J, Humphreys JE, Webster LO, Balakrishnan A, Keogh JP, Kunta JR, Serabjit-Singh CJ, Polli JW. In-vitro P-glycoprotein inhibition assays for assessment of clinical drug interaction potential of new drug candidates: a recommendation for probe substrates. Drug Metab Dispos. 2006;34:786-92.

9. Polli JW, Wring SA, Humphreys JE, Huang L, Morgan JB, Webster LO, Serabjit-Singh CS. Rational use of in vitro P-glycoprotein assays in drug discovery. J Pharmacol Exp Ther. 2001;299:620-8.

10. Kerbel RS, Kamen BA. The anti-angiogenic basis of metronomic chemotherapy. Nat Rev Cancer. 2004;4:423-36.

11. Jacquin JP, Chargari C, Thorin J, Mille D, Mélis A, Orfeuvre H, Clavreul G, Chaigneau L, Nourissat A, Dumanoir C, Savary J, Merrouche Y, Magné N. Phase II trial of pegylated liposomal doxorubicin in combination with gemcitabine in metastatic breast cancer patients. Am J Clin Oncol. 2012;35: 18-21.

12. da Rocha AB, Lopes RM, Schwartsmann G. Natural products in anticancer therapy. Curr Opin Pharmacol. 2001;1:364-9.

13. Cuellar N, Aycock T, Cahill B, Ford J. Complementary and alternative medicine (CAM) use by African American (AA) and Caucasian American (CA) older adults in a rural setting: a descriptive, comparative study. BMC Complement Altern Med. 2013;3:8-14.

14. Kaur R, Kapoor K, Kaur H. Plants as a source of anticancer agents. J Nat Prod Plant Resour. 2001;1:119-24.

15. Shu L, Cheung KL, Khor TO, Chen C, Kong AN. Phytochemicals: cancer chemoprevention and suppression of tumour onset and metastasis. Cancer Metastasis Rev. 2010;29:483-502.

16. Miele E, Spinelli GP, Miele E, Tomao F, Tomao S. Albumin-bound formulation of paclitaxel (Abraxane $\mathrm{ABI}-007$ ) in the treatment of breast cancer. Int J Nanomedicine. 2009;4:99-105.

17. Koduru S, Grierson DS, van de Venter M, Afolayan AJ. In vitro antitumour activity of Solanum aculeastrum berries on three carcinoma cells. Int J Cancer Res. 2006:4:397-402.

18. Drewes FE, van Staden J. Aspects of the extraction and purification of solasodine from Solanum aculeastrum tissues. Phytochem Anal. 1995;6:203-6.

19. Wanyonyi AW, Sumesh CC, Gerld M, Udo E, Wilson MN. Bioactive steroidal alkaloid glycosides from Solanum aculeastrum. Phytochemistry. 2002;59:79-84.

20. Munari CC, de Oliveira PF, Campos JCL, Martins SP, da Costa JC, Bastos JK, Tavares DC. Antiproliferative activity of Solanum lycocarpum alkaloidic extract and their constituents, solamargine and solasonine, in tumor cell lines. J Nat Med. 2004;68:236-41.

21. Vichai V, Kirtikara K. Sulforhodamine B colorimetric assay for cytotoxicity screening. Nat Protoc. 2006;1:1112-6.

22. Jia JX, Wasan KM. Effects of monoglycerides on rhodamine 123 accumulation, estradiol 17 beta-D-glucuronide bidirectional transport and MRP2 protein expression within Caco-2 cells. J Pharm Pharm Sci. 2008;11: 45-62.

23. Kars MD, Gündüz U, Üney $K$, Baş AL. Exploring a natural MDR reversal agent: potential of medical food supplement Nerium oleander leaf distillate. Asian Pac J Trop Biomed. 2013;3:644-9.

24. Flieger J. Alkaloids/thin-layer (planar) chromatography, in: Encyclopedia of Separation Science., New York, 2000;pp. 1956-73.

25. Sreevidya N, Mehrotra S. Spectrophotometric method for estimation of alkaloids precipitable with Dragendorff's reagent in plant materials. J AOAC Int. 2003;86:1124-7.

26. Koduru S, Jimoh FO, Grierson DS, Afolayan AJ. Antioxidant activity of two steroid alkaloids extract from Solanum aculeastrum. J Toxicol Pharmacol. 2007;2:160-7.

27. Neszmelyi A, Machytka D, Shabana MM. ${ }^{13}$ C NMR spectroscopy of solasodine glycosides from Solanum laciniatum. Phytochemistry. 1988;27: 603-5.

28. Blankemeyer JT, Mc-Williams ML, Rayburn JR, Weissenberg M, Friedman M. Developmental toxicology of solamargine glycoalkaloids in frog embryos. Food Chem Toxicol. 1998;36:383-9.
29. Nikolic NC, Stankovic MZ. Solanidine hydrolytic extraction and separation from the potato (Solanum tuberosum L.) vines by using solid-liquid-liquid systems. J Agric Food Chem. 2003;51:1845-9.

30. Al-Rehaily AJ, Ahmad MS, Mustafa J, Al-Oqail MM, Hassan WH, Khan SI, Ikhlas AK. Solanopubamine, a rare steroidal alkaloid from Solanum schimperianum: synthesis of some new alkyl and acyl derivatives, their anticancer and antimicrobial evaluation. J Saudi Chem Soc. 2013;17:67-76.

31. Lin HM, Tseng HC, Wang CJ, Chyau CC, Liao KK, Peng PL, Chou FP. Induction of autophagy and apoptosis by the extract of Solanum nigrum Linn in HepG2 cells. J Agric Food Chem. 2007;55:3620-8.

32. Yu S, Sheu H-M, Lee C-H. Solanum incanum extract (ST-100) induced melanoma cell apoptosis and inhibits established lung metastasis. Oncotarget. 2017:8:103509-17.

33. Kuo KW, Hsu SH, Li YP, Lin WL, Liu LF, Chang LC, Lin CC, Lin CN, Sheu HM. Anticancer activity evaluation of the Solanum glycoalkaloid solamargine: triggering apoptosis in human hepatoma cells. Biochem Pharmacol. 2000;60:1865-73.

34. Shiu LY, Chang LC, Liang CH, Huang YS, Sheu HM, Kuo KW. Solamargine induces apoptosis and sensitizes breast cancer cells to cisplatin. Food Chem Toxicol. 2007:45:2155-64.

35. Chen Y, Tang Q, Xiao Q, Yang L, Hann SS. Targeting EP4 downstream c-Jun through ERK1/2-mediated reduction of DNMT1 reveals novel mechanism of solamargine-inhibited growth of lung cancer cells. J Cell Mol Med. 2017;21:223-33.

36. Xie X, Zhu H, Zhang J, Wang M, Zhu L, Guo Z, Shen W, Wang D. Solamargine inhibits the migration and invasion of HepG2 cells by blocking epithelial-to-mesenchymal transition. Oncol Lett. 2017;14:447-52.

37. Esteves-Souza A, da Silva TMS, Alves CCF, de Carvalho MG, Braz-Filho $R$, Aurea E. Cytotoxic activities against Ehrlich carcinoma and human k562 leukaemia of alkaloids and flavonoid from two Solanum species. Braz Chem Soc. 2002;13:838-42.

38. Nekooki-Machida Y, Kurosawa M, Nukina N, Ito K, Oda T, Tanaka M. Distinct conformations of in vitro and in vivo amyloids of huntingtin-exon1 show different cytotoxicity. Proc Natl Acad Sci U S A. 2009;106:9679-84.

39. Junyaprasert VB, Soonthornchareonnon N, Thongpraditchote S, Murakami T, Takano M. Inhibitory effect of Thai plant extracts on P-glycoprotein mediated efflux. Phytother Res. 2006;20:79-81.

40. Sahu J, Rathi B, Koul S, Khosa RL. Solanum trilobatum (Solanaceae)-an overview. J Nat Remedies. 2013:13:76-80.

41. Li X, Zhao Y, Ji M, Liu SS, Cui M, Lou HX. Induction of actin disruption and downregulation of P-glycoprotein expression by solamargine in multidrugresistant K562/A02 cells. Chin Med J. 2011;124:2038-44.

42. Lavie YA, Harel-Orbital TO, Gaffield WI, Liscovitch MO. Inhibitory effect of steroidal alkaloids on drug transport and multidrug resistance in human cancer cells. Anticancer Res. 2001;21:1189-94.

43. Shapiro AB, Ling V. Positively cooperative sites for drug transport by Pglycoprotein with distinct drug specificities. Eur J Biochem. 1997;250:130-7.

44. Jia J, Zhu F, Ma X, Cao ZW, Li YX, Chen YZ. Mechanisms of drug combinations: interaction and network perspectives. Nat Rev Drug Discov. 2009:8:111-28.

45. Tai CJ, Wang CK, Tai CJ, Lin YF, Lin CS, Jian JY, Chang YJ, Chang CC. Aqueous extract of Solanum nigrum leaves induces autophagy and enhances cytotoxicity of cisplatin, doxorubicin, docetaxel, and 5-fluorouracil in human colorectal carcinoma cells. Evid Based Complement Alternat Med. 2013:1-12.

46. Anindyajati S, Putri DD, Hermawan A, Meiyanto E. Combination of Solanum nigrum L. herb ethanolic extract and doxorubicin performs synergism on T47D breast cancer cells. Indones J Chemoprev. 2010;1(2):78-84.

47. Ding X, Zhu FS, Li M, Gao SG. Induction of apoptosis in human hepatoma SMMC-7721 cells by solamargine from Solanum nigrum L. J Ethnopharmacol. 2012;139:599-604.

48. Liang CH, Liu LF, Shiu LY, Huang YS, Chang LC, Kuo KW. Action of solamargine on TNFs and cisplatin-resistant human lung cancer cells. Biochem Biophys Res Commun. 2004;322:751-8.

49. Friedman M, Lee KR, Kim HJ, Lee IS, Kozukue N. Anticarcinogenic effects of glycoalkaloids from potatoes against human cervical, liver, lymphoma, and stomach cancer cells. J Agric Food Chem. 2005;53:6162-9.

50. Xu Y, Zhi F, Xu G, Tang X, Lu S, Wu J, Hu Y. Overcoming multidrugresistance in vitro and in vivo using the novel P-glycoprotein inhibitor 1416 Biosci Rep. 2012;32:559-66.

51. El-Readi MZ, Hamdan D, Farrag N, El-Shazly A, Wink M. Inhibition of Pglycoprotein activity by limonin and other secondary metabolites from Citrus species in human colon and leukaemia cell lines. Eur J Pharmacol. 2010;626:139-45. 